Journal of the British Association for Chinese Studies, Vol. 9 (1), January 2019 ISSN 2048-0601

(C) British Association for Chinese Studies

\title{
Female Solidarity as Hope: A Re-Examination of Socialist Feminism in the Literary Works of Ding Ling and Christa Wolf
}

Yejun Zou

King's College London and the Humboldt University of Berlin

\begin{abstract}
Recent scholarship has questioned the validity of Western feminism as a model for feminist movements in contemporary China and highlights a gap in the scholarly understanding of the tradition and trajectory of socialist feminism in China (Song, 2012; Wang, 2017). In this article, I will examine the practicality of socialist feminism as an alternative model for contemporary Chinese feminism by comparing the depiction of women in the literary works of the Chinese writer Ding Ling and the East German author Christa Wolf. In Ding Ling's novel In the Hospital, she strives for gender equality via collaborative work between men and women, while incorporating this feminist task into the agenda of socialist revolution. Christa Wolf's novel The Quest for Christa T., in contrast, explores female friendship as a means of overcoming stagnation and cynicism in the GDR. I ask how both authors articulate their concerns and criticism of inadequate gender practices in socialist states through the lens of women's perspectives. This article thereby offers an insight into the way their writings negotiate women's concern with the official narrative of life in socialist states and the extent to which these texts illuminate alternative Chinese feminist approaches in a contemporary context.
\end{abstract}

Keywords: socialist feminism, comparative literature, women's writing, GDR, China, transnationalism, Christa Wolf, Ding Ling.

In recent years, scholars in China and abroad have been working on the current relationship between Chinese feminists and the state from various perspectives, calling for a re-examination of socialist feminism in contemporary China. ${ }^{1}$ In

${ }^{1}$ For instance, writing from a political and economic perspective, Song Shaopeng identifies a rupture in the knowledge of the socialist feminist legacy in China, particularly since the 1990s, where the privatisation of means of production and the retreat of the family into the private 
Finding Women in the State, Wang Zheng highlights the lack of attention given in Chinese feminist studies to the efforts of socialist state feminists to promote and implement policies for gender equality in the newly founded People's Republic of China (PRC), particularly from around 1948 to the early 1960s (Wang, 2017). While acknowledging Chinese feminists' efforts in campaigning for gender equality in China today, Wang Zheng points out that they could engage more with the legacy of socialist feminists' attempts to create a genderequal socialist state in the early period after the foundation of the PRC (19491964) (Wang, 2017: 25-26). In light of this observation, Wang Zheng calls for a re-examination of the overlooked history of socialist feminism in China and highlights a need to "inform young feminists of their foremothers' beautiful dreams, strong commitments, tenacious struggles, bitter frustrations, formidable constraints, serious limitations, and astonishing accomplishments" (Wang, 2017: 26). For Wang Zheng, a re-examination of the history of Chinese feminists in the early socialist state can inspire young Chinese feminists today to understand the achievements and the unexamined historical process of these movements. They can thereby discover new ways of organising and enacting feminist activism in contemporary China. In this sense, an insight into the history of and writings by feminists in socialist states can bring forth not only new pathways and understanding for feminists in contemporary China, but also illuminate the multidimensional relation between women and the state in recent history.

In this article, I respond to Wang Zheng's call for a re-examination of the legacy of socialist feminists from a comparative literary perspective. Scholars such as Wang have focused on state-feminist campaigns and attempts at implementing gender-equal policies in and through particular national state institutions. However, by examining the work of feminist writers in different socialist states, we can gain a sense of the diversity of socialist feminist thought and the multiple ways in which they envisaged the meaning of a gender-equal society under socialism. One of the important aspects to understand in this

sphere have been further enforced (Song, 2012). Similarly, Wen Liu, Ana Huang and Jingchao $\mathrm{Ma}$ also highlight contemporary feminists' reluctance to examine the official narrative of women's liberation during the Communist revolutionary era due to an eagerness to break from it. This reluctance, in turn, leads to a lack of investigation of the impact of the history of Chinese feminism upon contemporary Chinese feminist activism (Liu, Huang \& Ma, 2015). 
history is the way different feminist thinkers in socialist states regarded their relationship with the state's vision of the building of a socialist society as tense yet constructive, rather than antagonistic, as has been assumed by observers from Western countries. In order to explore this relationship, I will compare literary works of the former East German female author Christa Wolf from the early 1960s with texts from the 1940s by the Chinese female author Ding Ling. These two decades are important in terms of the personal literary trajectories of each writer, since it was in these decades that Wolf and Ding Ling attempted to grapple with both socialist theory and ideas about women's equality. Moreover, these decades were formative periods in the building of socialist state institutions in each country, and they saw the development of official policies toward gender relations as well as attempts to regulate literature and arts. The comparison that I put forward here transcends national and temporal boundaries, thereby shedding light on women writers' attempts to articulate women's voices and struggles beyond the framework of the individual nation state.

Transnational feminism as understood by Chinese feminists since 1995 is heavily conditioned by Western discourse. ${ }^{2}$ The comparison of women's writing in China and East Germany allows for a neglected history of transnational feminist movements in the "socialist East" to resurface, and, as a result, breaks away from the hegemonic discourse of transnational feminism operating in the "capitalist West". While I will not reconstruct a detailed genealogy of socialist feminism in China or Germany, and while Ding Ling and Christa Wolf may not have read each other's works per se, it is important to acknowledge how both

\footnotetext{
${ }^{2}$ Some Chinese feminists have regarded the Fourth World Conference on Women and its accompanying Forum of Non-Governmental Organisations held in Beijing in 1995 as an opportunity to engage in dialogue with the international feminist community (Hsiung \& Wong, 1999: 126). Since then, these feminists have increasingly sought help from Western feminist theory in order to account for and resolve the struggles that women face in contemporary China. The Fourth World Conference on Women enriches and adds to the complexity of Chinese feminism, which then interacts and creates tension with feminism in Western countries. However, prior to this international conference, Chinese feminists in the 1980s and 1990s also strove to re-conceptualise and account for new struggles and challenges that women faced in light of the rapid political and economic changes that emerged in a post-Maoist China (see Barlow, 2004: 253-354).
} 
are situated within the context of a longer history, since at least the early twentieth century, of the transnational circulation of ideas, texts, and movements that articulated the bringing together of socialism and feminism from different perspectives.

The legacy of this sphere of transnational socialist feminist thought and action played out differently in the rise of socialist states in both Germany and China, and in the mainstream practice of each of the leading communist parties of the two countries. ${ }^{3}$ Rather than recounting a broad history of socialist feminist thought and action in both contexts, I will focus on the particular socialist feminist engagement of these two prominent women writers in two early socialist regions. By focusing on the similarities and differences of the contexts of both authors, and their particular challenges in writing from a feminist perspective in these different contexts, this article offers an insight into how these two writers negotiated women's concerns in relation to the official narrative of life in socialist states and the extent to which their texts may illuminate alternative Chinese feminist approaches in the contemporary context. Both authors express their concerns about and criticism of failings and weaknesses in their own socialist societies through the lens of women's perspectives. The criticism made by these two female authors is not articulated from the perspective of rejecting the making of a socialist society, but from the perspective of understanding where it still needs to work for women. Both authors are committed to a socialist society, but, at the same time, they are critical of the approach that has so far been taken towards questions of gender equality and women's everyday lives. Such perspectives open up an important aspect of the diverse and contested history of feminist thought in socialist countries.

One of the questions that unites historical socialist feminist thought with contemporary feminism, including in China, is that of solidarity between women, and between men and women, in working toward a gender-equal

\footnotetext{
${ }^{3}$ Scholars like Christina Gilmartin have shown that the CCP leadership in China took a more conservative Stalinist approach to the question of feminism from the 1920s (see Gilmartin, 1995; Stranahan, 1983). Similarly, scholars such as Georgina Paul, Birgit Mikus and Emily Spiers have also highlighted a "fractured legacy" of the socialist feminist movement in Germany (see Mikus \& Spiers, 2016; Paul, 2009).
} 
society. Given all the differences of class and culture, and the divided allegiances between women, how can these be both taken account of and brought together to create a society free of oppression and inequalities, including those based on gendered hierarchies? Writing in 2004, Dai Jinhua already posed the issue of class differences amongst women as a neglected aspect of contemporary Chinese academic and literary feminism in the post-1980s (Dai, 2004). It has also been brought to the fore in recent years by emerging poetry from the dagongmei 打工妹, or rural women migrant workers in China's factories (Dooling, 2017), whose expressions of the intersections of class, livelihood precarity and gender are an important reminder of the question of feminist solidarity for today's young university-based feminists who might turn more to their counterparts transnationally, rather than locally, for expressions of solidarity.

In this article, I will examine the ways in which both Ding Ling and Christa Wolf foreground the question of solidarity for women in their presentation of the building of a gender-equal socialist society that takes into account the experiences of women. While Christa Wolf envisages female friendship as an alternative human interrelationship that has the potential of overcoming the rigidity and dogmatism caused by male dominance in the GDR, Ding Ling imagines a collaborative work between men and women from different social and class backgrounds, through which a truly gender-equal society that is inhabitable for women can emerge. By reading the literary works of both authors, feminists today can learn from the ways in which both authors present hopeful expressions of female solidarity while maintaining a critical stance towards their respective socio-political circumstances. Literature supplements what reality lacks and helps us imagine and understand the multiplicity, complexity and diversity of women's struggles within human relations in a way which can transcend temporal and historical frameworks.

\section{Communist Women, Feminism and Socialist Feminism}

In the Western context, the term "feminism" connotes the political and social movements that seek to establish women's rights in various spheres in society and equality between men and women; by way of contrast, this term does not 
have a straightforward equivalence in the Chinese context. ${ }^{4}$ The two Chinese terms that have been used most commonly in recent years are nüxing zhuyi 女 性主义 (feminine-ism) and nüquan zhuyi 女权主义 (the ism of women's rights)

(Wang, 2000: 737). These two Chinese terms are used almost interchangeably nowadays, yet the subtle difference in translation should not be overlooked. While nüxing zhuyi accentuates the essence of gender (difference)-xing(bie), nüquan zhuyi emphasises the rights of women-quanli 权利. ${ }^{5}$ The Chinese character quan 权 can also be expanded into quanli 权力, which indicates a sense of power. In this regard, nüquan zhuyi implies a more radical connotation than nüxing zhuyi in a contemporary context, as it indicates the process of empowering women through emphasising their rights and power.

The place of feminism and its naming in the nationalist and communist movements of the early and mid-twentieth century is also a complex one. Introduced in the early twentieth century from foreign, mostly Japanese, feminist texts, the Chinese term nüquan was popularised along with the New Culture Movement-a movement that strove to transform Confucian moral and cultural practices and thus modernise Chinese culture around the 1920s (Wang, 2017: 3). The young Chinese Communist Party (CCP) of the 1920 s saw a nüquan yundong 女权运动 (movement for women's rights and power) as appealing because these feminists demanded an improvement of women's living conditions from a nationalist perspective, which aligned with the anti-imperial nationalism of the CCP (Gilmartin, 1995: 7). During the Party's formative phase Chinese communists collaborated with Chinese nüquan feminists in an attempt to bring about a social revolution (Barlow, 2004: 53-5). In the 1930s, however,

\footnotetext{
${ }^{4}$ It should, however, be noted that the term "feminism" does not have an unequivocal definition in the West either. Disagreement still occurs within different branches of feminism with regards to the interpretation of struggles that women face under male dominance, as well as approaches to act against or resolve these forms of oppression (James, 1998: 576; Haslanger, Tuana \& O'Connor, 2017).

${ }^{5}$ As Tani Barlow suggests, the term nüxing, which erupted into circulation during the 1920s, essentialises sexual difference and the male/female binary, and acts as a signifier of resistance towards the Confucian tradition (Barlow, 2004: 52-3). However, Liu, Karl and Ko demonstrate that the neologism nüxing appeared as early as the turn of the twentieth century, whereby xing was understood in the Confucian tradition as nature/humanity, rather than (female or male) sex (Liu, Karl \& Ko, 2013: 16).
} 
the CCP took a more conservative approach, echoing that of the Soviet Union under Stalin and other Western communist parties under the influence of the Comintern (Boxer, 2007). During this period, women communists in China and across the Comintern world continued to press for a deep-seated social revolution of gender relationships (Boxer, 2007; Riddell, 2011; Gilmartin, 1995), even as the male-dominated leaderships of communist parties took more conservative approaches. At the same time, the term "feminism" itself was often rejected by communist women, since it was associated with the movement of bourgeois women seeking the rights of bourgeois men in a capitalist society, with little regard for larger economic and political inequalities that affected women and that needed a more thorough social and political revolution (Barlow, 2004; Boxer, 2007; Wang, 2017). ${ }^{6}$

Both Ding Ling and Christa Wolf participated in, and were inheritors of, a tense relationship between women activists striving for a transformation of gender relationships within the socialist projects of different communist parties and socialist organisations from the 1930s onwards, and the often maledominated leaderships that were committed to a gender-equality agenda but often downplayed the concerns of women. In this sense, we may see them as part of a longer history of "socialist feminism", a term that may well capture the particularity of feminist agendas within socialist projects, while also indicating the struggles that these feminists faced. Indeed, the term "socialist feminism" was not one that was widely used by feminist activists in communist parties themselves. Neither did they often call themselves "feminists", due to the term's association with "bourgeois feminism". The term "socialist feminism" gained currency instead in the 1960s and 1970s in the post-second-wave feminist movements of North America and Western Europe, though it was heavily influenced not only by what Western feminists perceived as the more radical gender equality projects occurring in socialist countries like China, but also by a similar set of core socialist texts on the question of women that had

\footnotetext{
${ }^{6}$ For instance, Clara Zetkin and Alexandra Kollontai believed that the organised communist women's movement was able to bring about a socialist revolution that would overturn capitalism, while bourgeois feminist movements merely led to reform, which was not able to eliminate capitalist domination - the roots of women's oppression - in all social aspects (Zetkin, 1896; Kollontai, 1909). These Western female communists had a decisive impact on the Chinese female communists (Gilmartin, 1995).
} 
also been the basis of communist and socialist women's movements since the late nineteenth century (Hathaway, 2018). "Socialist feminism" indicated an understanding of the roots of women's oppression in both capitalist domination and gender oppression (Ehrenreich, 1976; Buchanan, 2016). From the perspective of socialist feminists, mainstream feminism focuses too narrowly on the roots of women's oppression in social and cultural realms and through the universality of male supremacy (Ehrenreich, 1976). The term "socialist feminism", then, was coined in order to emphasise that "gender and class are mutually reinforcing systems of oppression" (Buchanan, 2016). Though neither Ding Ling nor Christa Wolf labelled themselves explicitly as "socialist feminists", this term is used here as an heuristic tool to describe their feminist writings, which presented a critique of the way the socialist projects in their particular countries had so far dealt with questions of gender inequality and women's experiences, but also attempted to do so from a perspective that saw the socialist project as a pathway for a feminist project. Through referring to both authors as socialist feminists, I regard them as the heirs of the aforementioned legacy of the communist women's movements of the early twentieth century and, at the same time, the forbearers of contemporary transnational socialist feminists.

\section{Ding Ling and Christa Wolf: Controversial Feminists}

Both Ding Ling and Christa Wolf engaged with women's experiences under socialism in their writings throughout their literary careers, be it implicitly or explicitly, and both gained considerable reputations. Ding Ling entered the Chinese literary scene in the 1920s, with stories exploring figures of "new womanhood", feminine psychology and sexuality. She was best known for her literary work Miss Sophia's Diary (1928), which explores a young urban woman's subjective feelings and sexual drives, pointing towards an emancipation of women on both physical and psychological levels. After joining the communist party in 1932, she brought her feminist literary perspective into productive tension and interaction with socialist narratives of class and collectivity. By contrast, Christa Wolf joined the Socialist Unity Party (SED) of the GDR in 1949 and established her literary reputation in the 1960s with her early socialist realist novel The Divided Heaven (1963), which examines the advantages and 
challenges of living in the GDR in the 1960s, concluding with a broadly optimistic view of the future of the socialist state. Wolf later developed a mode of experimental semi-autobiographical narration, termed subjective authenticity, which enabled her to explore the gendered relationship between self and history. In spite of their differing personal, temporal, cultural, and political contexts and modes of writing, the works of both writers can be brought into fruitful conversation through their critical perspectives on the problems hampering the progress of women's liberation under socialism.

Although Ding Ling and Wolf regarded themselves as engaging in productive criticisms of socialism from the perspective of those committed to seeing its realisation, they were perceived by their respective contemporary peers as denigrating the socialist project. The late 1960s saw a turning point in the development of socialist literature in the GDR, especially after the Eleventh Plenum of the Socialist Unity Party in 1965, which tightened state regulation of arts and literature and demanded that all artistic production present a positive attitude toward the SED (Fulbrook, 2004). To a certain degree, these regulations, influenced by the official Soviet literary policy of socialist realism, limited the creativity of writers and artists through imposing a depiction of everyday life in the GDR in positive, and even glorified tones. ${ }^{7}$ Dismayed by the

strict control of the SED, Wolf gradually turned away from state-sanctioned socialist realism and accentuated the significance of imagination and the incorporation of the subjective perspective of the author in literature (Tate, 2007). Wolf's loss of faith in the status quo in the GDR, which can be seen in The

Quest for Christa T. (1968a), led to criticism of her from across the political spectrum in both East and West Germany. While scholars in the GDR criticised Wolf's text as providing something for the West German critics to attack (Sachs, 1969; Adameck, 1969; Kähler, 1969; and Haase, 1969), scholars in the Federal Republic interpreted the novel as revealing symptoms of the failings of socialism (Reich-Ranicki, 1969; Mayer, 1970; Wiegenstein, 1969; and von Ankum, 1992).

Similarly, Ding Ling's Zai yiyuan zhong 在医院中 (In the Hospital) (1941a) was

\footnotetext{
${ }^{7}$ Although the official state policies on socialist realism restrained writers and artists in many ways, it did not prevent writers and artists from experimenting with the idea of socialist realism in different ways from the 1930s to the 1960s in the German context (see Subiotto, 1994; Tate, 1998).
} 
criticised soon after its publication in 1941. In this text and her critical essay "Thoughts on March 8" (1942a), Ding Ling articulated her concern with the unequal treatment of women in the Communist base area in Yan'an; at the same time, she took a critical perspective on women's own progress toward transforming gendered social relationships. This is demonstrated, on the one hand, in her criticism of the urban intellectual sentimentality of the female protagonist in In the Hospital and, on the other hand, in the emphasis in her essay on the need for women to develop their strengths. Ding Ling's critical stance towards unequal gender practices in Yan'an and women's need for selfimprovement shares a similar intention to that of Wolf-both strove to reflect on aspects of their respective socialist societies that could still work better for women.

As in Wolf's case, Ding Ling's understanding of socialism and its need for improvement from the perspective of women was obscured, and thus misinterpreted and criticised, at a time when literature and arts were constrained to depicting positive aspects of the revolutionary base area. The novel was written in the Communist base area of Yan'an during the period of the War of Resistance against Japan and much political turbulence in China. ${ }^{8}$ During this period, the CCP faced both external and internal exigencies: on the one hand, as the CCP was defeated by the Guomindang (GMD), or the Nationalist Party, in urban areas, it relocated its base to a remote rural area; on the other hand, the War of Resistance against Japan broke out in 1937, threatening the security of people and the sovereignty of China. In this context, the main task for the CCP was to strengthen its regime power and fight against Japanese fascism (Feuerwerker, 1982: 89-121). Literature at this time, as theorised by many nationalist leftist and communist writers, had a twofold function: literature should inspire soldiers to fight on the front and strengthen the solidarity of the people; it should also promulgate socialism, allowing more people, especially peasants in rural areas such as Yan'an, to understand the mechanisms and importance of socialism in China (Hong, 2007).

\footnotetext{
${ }^{8}$ The Yan'an base (1935 to 1950) was not a state per se, but is often seen as a microcosm of what later became the state apparatus of the socialist PRC (Apter \& Saich, 1994). Furthermore, it was in Yan'an that the literary and arts policy of the PRC was developed (see McDougall \& Louie, 1999).
} 
After arriving at the Yan'an revolutionary-base area in 1936, Ding Ling became one of the influential writers who helped institutionalise new ideas about revolutionary literature and culture promoted by the CCP and other leftist writers' associations. There were two writers groups in Yan'an during that time, leading the literary orientation in the revolutionary period. Ding Ling belonged to the All-China Writer's Resistance Association or Wenkang 文抗, while other prominent figures, such as Zhou Yang, spoke forwriters at the Lu Xun Academy or Luyi 鲁艺. These two groups shared multiple similarities, as Tani E. Barlow maintains, although "the Luyi group appears to have eventually moved toward a principled emphasis on 'praising brightness', whereas Wenkang placed relatively more emphasis on 'exposing darkness'” (Barlow, 2004: 193). Barlow's statement accounts for Ding Ling's call for zawen $\square$ 文一 the critical essay —in depicting life in Yan'an, which was first supported by Mao Zedong until the outbreak of the "Wang Shiwei incident". ${ }^{9}$

For Ding Ling, the importance of zawen lies more in its critical attitude towards social problems than in its literary style (Ding Ling, 1941b). Her laudatory but critical view of socialism and women was thus in accord with this belief in a critical stance toward reality. Yet after the Wang Shiwei incident, intellectuals involved in criticising the Party's structure and exposing the negative aspects of life in Yan'an were under attack. While Ding Ling made a timely token self-criticism to avoid further punishment, Wang Shiwei refused to back down from his views on inequality in Yan'an, resulting in him being executed after five years of detention due to the charge of Trotskyism. ${ }^{10}$ Although both Mao and the intellectuals working in Yan'an both aimed at

\footnotetext{
${ }^{9}$ Wang Shiwei published his zawen “Ye Baihehua” 野百合花 in March 1942, which exposed the Party's hierarchical structure in Yan'an and was reprinted by the GMD in a Xi'an newspaper, using it to attack the CCP. After that, zawen were no longer supported by the CCP and writers involved with them were criticised (Rubin, 1981:509).

${ }^{10}$ While both Ding Ling and Wang Shiwei articulated similar criticisms of certain structures in the Party, the reason for their different fates remains controversial. For instance, Yin Qi and Gao Hua interpret Mao's varying decisions on Ding Ling and Wang Shiwei as the result of his own political ambition (Gao, 2000; Yin, 2004). While this interpretation appears to overlook the broader context of historical contingency in Yan'an, Mao's paradoxical act seems to account for this type of reading - the purge of Trotskyists aligns with Stalin's policy, yet Mao's persecution of those accused of "Trotskyism" aims contradictorily at reducing the Comintern's influence on the CCP.
} 
criticising and transforming the hierarchies that emerged in the leadership and institutional organisations, their divergent interpretations of the hierarchy in the CCP led to the repression in Yan'an.

Despite both authors facing criticism and, in Ding Ling's case, punishment, due to their outspoken views about the inadequate progress toward true gender equality and freedom for writers under socialist regimes, the different political contexts in which both authors were writing should not be overlooked. The GDR was a relatively stable state in the 1960s, where writers were able to experiment with various literary techniques and expose social and political problems under the SED regime (Fulbrook, 2004). Yan'an in the 1940s remained in a wartime situation, in which the space for writers to explore diverse themes and techniques in literature was restricted. The literary and arts policy set in place after Mao's Talks in 1942 continued into the 1950s as the PRC state established itself. There was a brief period of officially-sanctioned artistic experimentation where criticism of the problems of the new socialist society was openly called for during the Hundred Flowers Campaign of 1956, but this space was soon closed again-with many writers who took up the call for critical perspectives facing much persecution. ${ }^{11}$

It should be noted that both Ding Ling and Christa Wolf encountered criticism under specific historical contexts where the form and content of literature were restricted by Party guidelines. While Wolf had an ambivalent relationship with the SED due to its rigid, ideologically-oriented literary policies, Ding Ling was in a more precarious situation in wartime Yan'an, where nationalism and socialism could not be easily disentangled in literature. It may seem that the particularly restrictive situation Ding Ling faced in Yan'an precluded the possibility of literary experimentation which Wolf was able to explore in the German context, but Ding Ling's complex depiction of her fictional characters and her ability to capture the multiple aspects of the subjective and objective difficulties people experienced in the revolution actually reveal a literary creativity that is different from that of Wolf. A comparison of both writers can therefore help to understand an international field of socialist feminist writing in the socialist world. When examining the way in which they both elicited similar sets of

${ }^{11}$ For the Hundred Flowers Campaign, see for instance MacFarquhar (1966). On the Anti-Hu Feng Campaign of 1955, in which Ding Ling, too, was particularly a target, see Denton (1998). 
questions about the socialist project implemented in their different contexts and feminism, as well as the tensions between them, we can also understand that these two women were different types of writers with different individual circumstances, which engendered their particular creative styles. Faced with the praise of their literary talent and criticism of their outright social critique at the same time, these authors' experiences of writing in socialist states indicate that they each had the determination to overcome difficulties in order to make their critical voices heard.

\section{Imagination and Female Solidarity in The Quest for Christa T.}

Both Ding Ling and Christa Wolf aimed to cultivate a better future for socialism through their criticism of the inadequacies in their respective socialist states, especially in terms of social and personal relationships between people as well as between state officials and ordinary people. They exposed the various struggles that women faced in both the private and public spheres, revealing the flaws in existing policies that should ideally ensure gender equality. Nevertheless, the criticism expressed in their writings should be regarded as a call for an improvement of the existing social and political system, rather than a complete overturn, as both expressed their hopes for and alternatives to a socialist future. Both authors draw on their own experiences as women in socialist regimes, and their texts provide alternative narratives of life under socialism that are different from the official narratives put forward by the regimes. In fact, through exposing shortcomings regarding struggles faced by women in socialist states, both authors seem to have envisaged a revitalised version of socialism with a sense of female solidarity at its core.

The novel The Quest for Christa T. narrates a recollection of the life of, and the narrator's relationship with, the protagonist Christa $T$, who dies of leukaemia at the age of thirty-five. The narrator and Christa T. meet for the first time in school during the Second World War and again during their studies at the University of Leipzig in 1952. The structure of the novel is complex on both a narrative and a formal level. The text comprises three layers of narrative: the authentic manuscripts of Christa T.'s diaries, letters and other writings, the narrator's interpretation of these materials, and the narrator's imaginative 
recreation of Christa T.'s life episodes. The interplay of the factual, the interpretive and the inventive accentuates the complexity of the content, as it supplements the narrative with the narrator's and the author's consciousness. Moreover, the shifting perspectives between the narrator and the protagonist, which blur the boundary between these two characters, also challenge the reader (Kuhn, 1988; Tate, 2007).

Criticism of gender inequality is not explicit in this novel; nevertheless, it is embedded in depictions of the various struggles encountered by the female protagonist (Kuhn, 1988). The significance of gender lies in the text's portrayal of women's experiences and struggles in the GDR. In her depiction of the friendship between the narrator and Christa T., Wolf develops an "alternative model of human interrelationship" (Kuhn, 1988)-that is, she depicts a female friendship, which can, to some degree, be interpreted as an alternative to the socialist system dominated by male technocrats in the GDR (Mohr, 1971; Huyssen, 1975).

In the novel, male characters are often depicted as pragmatists who do not think creatively. These men are, in Christa T.'s words, "Tatsachenmenschen"the type of person who follows rules unequivocally and seeks truth in "Tatsachen" (facts). For Wolf, this type of person does not examine the so-called facts and believes that what is presented before him cannot be changed; he therefore believes that one should always adapt to given circumstances. For instance, a male medical student suggests to Christa T. that she should conform to social norms, because "the essence of health is [to] adapt or conform" (The Quest for Christa $T$., hereafter CT, 111). And the school principal, an old man who went through the Second World War, after solving a quarrel between Christa T. and her pupils, advises her: "Learn to keep your own thoughts to yourself, it's what makes life liveable" $(C T, 104)$. These responses from men imply a compliance with given rules and an inability or unwillingness to take into account other people's differing beliefs, which is precisely what Wolf opposes. Such inflexibility of thinking precludes the consideration of alternative possibilities in reality. Dogmatically following rules does not allow for voices articulated from various perspectives to be heard, nor does it allow creative thinking to take place. Conformity then becomes the main principle in society, which prevents further development or improvement of society. 
Apart from dogmatism and rigid ways of thinking, male figures in the novel also represent violence. Wolf challenges the official narrative of the past put forward by the GDR regime, which, Wolf believes, does not address the past of National Socialism enough and hinders the development of East German society (Hell, 1997). The emphasis on two intertwined concepts in the GDR - "antifascism" and "socialism" - "affected a comprehensive cleansing of the GDR population's collective memory, unburdening many people of feelings of guilt" (Münkler, 1996: 124). In the novel, for instance, Christa T. witnesses her pupil Hammurabi biting off a toad's head for a bet, which triggers flashbacks of violence that happened in her childhood. Wolf's depiction of the past, represented predominantly by male violence in the novel, serves to give a better understanding of the present. From Christa T.'s memory of the male landlord who casts the tomcat at the wall, breaking its bones, to her recent encounter with Hammurabi, these men represent a repressed and unprocessed National Socialist past which threatens to re-emerge (Kuhn, 1988; Hell, 1997). The lack of overt discussion of this past transmutes itself into physical manifestations of violence, which, for Wolf, point to the stalled reflection on the National Socialist past in the GDR as a whole. In this sense, the depiction of men in the novel highlights the emerging failings in East Germany that prevent socialism from further development.

In contrast to the latent violence inherent in men's relationships with one another, the female friendship in the novel suggests a more positive mode of human interaction. Myra Love argues that The Quest for Christa T. exhibits a germinally feminist quality, found in the subversive potential of female subjectivity embodied by Christa T., and in the relationship between the narrator and the protagonist as a counter-patriarchal example of female friendship and solidarity (Love, 1979: 37). Although Wolf's depiction of men and women seems to fall into a static binary, it signals, nonetheless, her effort to establish a less dogmatic socialist society in the late 1960s. Love also relates Wolf's experimental writing mode to an act of counter-patriarchy and sees the relationship between the narrator and Christa T. as an alternative to men's experience in the GDR. From this perspective, the female friendship represented in Wolf's novel anticipates a budding feminist concern and envisages a less restrictive form of socialism, which is in turn linked to Wolf's appeal to the capacity of imagination. 
Wolf regards literature as a way to cultivate and develop the human faculty of imagination. In The Quest for Christa $T$., the importance of the ability to imagine is demonstrated through the narrator's imaginative reading of Christa T.'s diary and her life episodes. For instance, the narrator intends to interview Gertrud Born, one of Christa T.'s best friends, to know more about the protagonist. However, Wolf presents us with a counterfactual narrative, in which the entire interview with Gertrud Born is imagined by the narrator (CT, 50). Rather than being a false or inaccurate interpretation of Christa T.'s diary and life, this imaginative episode allows the narrator to explore her friend's life in supplement to what has already happened in reality. Similarly, Christa T. rewrites the incident where Hammurabi bites off a toad's head, changing the violent child into a repentant one in her literary imagination. The imaginative meeting, along with the toad story, can be seen as a means of endowing an individual's life with more open possibilities. In other words, literature supplements reality and presents what has not happened in reality as a potentiality. For Wolf, imagination through literary recreation helps move away from restrictions and stagnation in society (Wolf, 1968b: 202).

In The Reader and The Writer, Wolf writes: "We seem to need the help and approval of the imagination in our lives; it means playing with the possibilities open to us" (Wolf, 1968b: 190). Wolf believes the ability to imagine is a form of protection against "a furtive process hard to avoid, a hardening, petrifying, habituating, that attacks the memory in particular" (Wolf, 1968b: 190). Literature, according to Wolf, allows individuals to be creative, through which an apathetic, cynical and self-denying attitude towards life can be prevented. For Wolf, cynicism and dogmatism are similar to the troubling cynical latebourgeois attitude that regards humanism as an anachronism to be relegated to primitive societies or the prehistoric epochs (Wolf, 1968b: 210). In Wolf's account, "humanism" refers to the way individuals maintain their individuality within the collective and the importance of living a full life as human beings; these concerns, she argues, can be resolved by writing and reading literature. Wolf refuses the mimetic depiction of reality, which, according to GDR cultural policy of the period, ought to be the main, if not the only, type of depiction of reality in socialism; instead, the appeal for an imaginative portrayal of reality and the focus on the subjective perspective of individuals, though criticised by her contemporaries as bourgeois subjectivism, show that Wolf calls for a diverse 
and non-restrictive understanding of socialism, in which the individual and the collective reinforce each other mutually.

Wolf's call for a less restrictive socialist society cannot be achieved without narrating her novel from a female perspective. As Myra Love points out, the female friendship between the narrator and Christa T. plays a pivotal role in achieving this vision of socialism. For Love, the similar experiential worlds between the narrator and Christa T. facilitate the female solidarity between them. She argues that Christa T. is placed on the periphery of society due to her openness to subjective experience and her questioning of authority, presented in the novel as her inability to conform. In solidarity with Christa T., the narrator, through appropriating Christa T.'s mentality, seizes "the utopian potential of a historically female subjectivity" (Love, 1979: 42). After Christa T.'s death, the narrator rediscovers the value of certain qualities that Christa T. possessed, such as resistance to conformism and openness to different possibilities; through this discovery and through her reading of Christa T.'s process of self-actualisation, the narrator also begins to go through the same process herself.

Although Christa T. cannot be regarded as an idealised socialist heroine in the novel, she is, for the narrator, a role model of the way women experience reality differently than men. Furthermore, the narrator, to some degree, extends Christa T.'s existence by taking over her articulated voice. Christa T.'s voice is articulated less frequently as the novel develops; instead, the narrator's voice becomes more prominent and increasingly interferes with Christa T.'s voice. This shows that, on the one hand, Christa T.'s qualities and experience are transferred and appropriated in the narrator's extended account of her story; on the other, the extended voice by the narrator signifies a solidarity through female friendship. For Wolf, a better prospect for socialism lies in both the capacity to imagine and a resistance to dogmatic thinking, which can be achieved through positioning female bonding into the apparatus of the socialist state.

\section{Gender Inequality and a Socialist Future in In the Hospital}

Faced with increasingly strict policies on literature and the arts, Christa Wolf 
explores female solidarity as a means of combating male dominance and rigidity in the GDR. By contrast, for Ding Ling, female solidarity is created through the collaborative work of both men and women of different classes, all of whom have much to overcome personally and relationally, before they can achieve a gender-equal socialist future. In her seminal essay "Thoughts on March 8", Ding Ling expresses her concern that the specific struggles that women, especially urban female intellectuals, faced were not properly addressed and recognised by political authorities-predominantly male-and by women themselves in Yan'an (Ding Ling, 1942a; Barlow, 2004). At the end of this essay, Ding Ling puts forward four suggestions for women so that they can strengthen themselves physically and mentally: stay healthy; search for happiness; think rationally; stay resolved in hardship and persevere to the end (Ding Ling, 1942a). Ding Ling's concerns as stated in her essay, as well as her suggestions to women, are fictionalised in her novel In the Hospital, which complicates the question of the representation of women, because the fiction, as Barlow suggests, keeps open "the problem of the difficulty in literature or policy writing of ever getting women properly represented in the final instance" (Barlow, 2004: 220). However, it is this openness to the complexity of women's struggles that allows Ding Ling to create a space in her literary writing, in which a solidarity for women in the cultural and political spheres can be imagined.

In the Hospital depicts the story of a twenty-year-old woman Lu Ping who stays for a short time in a hospital in a small village not far away from Yan'an. Lu Ping is from the coastal metropolis of Shanghai, where she trained as a midwife in the university. After joining the communist party, she resolutely commits herself to the revolution, even though she is assigned to a hospital in a dilapidated area. After arriving in the hospital, the inhospitable reception, the poorly equipped environment and the irresponsibility of the leaders towards the staff contrast starkly with Lu Ping's idealised vision of the revolution. In spite of all this, Lu Ping's determination and enthusiasm are not weakened; instead, she dedicates herself to her duties and assiduously takes care of the patients. After a stressful operation where tragedy nearly occurs due to the inadequacy of equipment, however, Lu Ping isolates herself from the others, as she becomes ill. Toward the end, before Lu Ping leaves the hospital for further studies, she feels both dismayed and discouraged; yet, a conversation with a patient rekindles her optimistic belief in the future and reinforces her 
determination and commitment to the revolution.

The character Lu Ping summarises the problems that urban intellectual women faced in the revolutionary region-their "modernised" vision of the revolution clashes with the rudimentary hygiene, the poor quality of facilities, and the lack of gender-equal awareness and political consciousness in Yan'an. At the same time, the narrator takes a critical stance toward the female protagonist, through which Ding Ling also expresses her critique of the idealistic feminism embraced by urban intellectual women. For Ding Ling, urban intellectuals, both men and women, have a tendency to idealise and fantasise about reality in the revolutionary period (Ding Ling, 1942a). In the case of Lu Ping, her enthusiasm towards the revolution is driven by her rosy fantasy, rather than a rational evaluation of reality.

Lu Ping's difficulty in reconciling her political ambition with reality is further demonstrated through the narrative emphasis on her inner perspective: "[s]he was full of imagination and is able to open up possibilities in her life. But the iron hoop of 'the Party' and 'the need of the Party' is tied around her head, how could she disobey the demand of the Party? How can she ignore the hoop, which she has tied on herself?"12 (In the Hospital, hereafter Hospital, 240). The free, indirect style here blurs the third-person voice of the narrator with the subjective viewpoint of the protagonist. The depiction of Lu Ping's inner perspective recalls that of Ding Ling's earlier female protagonist Shafei (Sophia) in Miss Sophia's Diary, as both seem to be caught up in their own consciousness. ${ }^{13}$ Both female characters are dismayed by the actual circumstances that do not live up to their expectations: Shafei committed suicide when she realised her sexual desire was incompatible with the society she was in, whereas Lu Ping becomes ill when her rose-tinted vision of revolution is shattered by the reality she sees in Yan'an.

Though not as extreme as Shafei's choice to end her life, Lu Ping's illnessneurasthenia, or nervous weakness, and insomnia-reminds the readers of her

\footnotetext{
${ }^{12}$ Translations of In the Hospital are my own.

13 This similarity of the two female characters was also noticed by some of Ding Ling's contemporaries, such as Zhou Yang, but they used it to condemn Ding Ling as following the bourgeois literary tradition of subjectivism (see Zhang, 1958).
} 
background as a progressive petit bourgeois woman, as these illnesses are often used to depict urban women's "hysteria" in literature, indicating modern women's struggle in society and their nascent female awareness (Dikötter, 1995). While Shafei demonstrates Ding Ling's earlier thoughts on the awakening of women's self-consciousness and sexuality, and the difficulty for women to become autonomous subjects, Ding Ling's understanding of women's struggle in the 1920s was limited to a focus on urban intellectual women. Lu Ping, by contrast, exemplifies Ding Ling's awareness of a trans-class feminism. For Ding Ling, Lu Ping should not be a perfect character, "she should possess the weakness of the petite bourgeoisie"; but when she exposed her own failings, she has the chance to overcome them and complete the process of transformation into a stronger character (Ding Ling, 1942b). Here, Lu Ping's neurasthenia represents Ding Ling's critical view of urban women's weaknessthat is, their irrationality and sensitivity, which, nonetheless, can be overcome by following the four self-strengthening guidelines for women outlined by Ding Ling in her "Thoughts on March 8". For Ding Ling, the fourth piece of advice"stay resolute in hardship, persevere to the end"-is perhaps the most significant one, which echoes with the novel's aphoristic ending: "people grow up in hardship" (Hospital, 253).

During her time in Yan'an, Ding Ling conceived women not through the lens of urban femininity, which excludes peasant and working-class women, but through the recognition of geographical, cultural and political differences. Ding Ling's shift prompts her to explore the complexity and difficulty of the literary representation of "woman", "in the context of cultural and social grids mediating direct historical experience", which, in turn, creates a space in which a solidarity in all areas for women can be imagined (Barlow, 2004: 220). Ding Ling's understanding of "woman" as a trans-class category is tied to her own experience of urban female intellectuals' inadequate understanding of women's liberation. In her first experience of performing Xixiangji 西 $\square \square$ (Romance of the West Chamber) on stage in Shanghai in 1922, Ding Ling recalled that everyone wanted to play the leading role while no one but her best friend Wang Jianhong and herself was willing to play the maids (Ding Ling, 1982a: 161). Since she originated from the gentry, Ding Ling's act of performing as a lowerclass woman signifies "a transformation of her own given placement in the class hierarchy and ends the myth of the 'naturalness' of its existence" (Yan, 2006: 
205).

This act of transcending class hierarchy allows Ding Ling to see the limited interpretation of gender emancipation by women with privileged backgrounds, exposing the way they re-inscribe a power structure based on class hierarchy rather than gender hierarchy. While the experience in Shanghai prompts Ding Ling to gain awareness of the relation between gender and class, her life in Yan'an deepens her understanding of both, bringing these struggles together. For Ding Ling, the actual agrarian "labour and hardship in Yan'an washes off a lot of her old sentiments, while bringing her new habits. This internal and subtle change that can only be perceived by herself affects her attitudes towards other things as well" (Ding Ling, 1950a; Li and Wang, 2015: 203). ${ }^{14}$ Ding Ling implies that her labour and life in the early Yan'an years transform her limited and classdetermined understanding of women's liberation into an awareness of the interrelationship between class and gender.

By exposing the limits of urban intellectual women's understanding of "woman", Ding Ling proposes a female solidarity in socialism that comprises a class awareness amongst women from different backgrounds that can potentially overcome women's own failings. As she writes in "Thoughts on March 8": "We must also hope for a little more from our women comrades, especially those in Yan'an. We must urge ourselves on and develop our comradely feeling" (Ding Ling, 1942a: 319). Here, Ding Ling calls for a female solidarity that has the potential to overcome the weakness women possess, as she further maintains that "if women want equality, they must first strengthen themselves" (Ding Ling, 1942a: 319). But for Ding Ling, equality for women cannot be achieved without collaboration with men, as she believes "it will not be fully effective and women's thorough emancipation cannot be achieved if the other half of the population-men-does not participate in the emancipation" (Ding Ling, 1942b). ${ }^{15}$ In other words, Ding Ling regards the lack

\footnotetext{
${ }^{14}$ This essay titled "Laodong yu wo" (Labour and I) written in the early 1950s was not published until Ding Ling's last secretaries included part of it in their work Ding Ling zhuan 丁玲 $\square$ (Ding Ling's biography) (2015).

${ }^{15}$ Ding Ling articulated this claim in her self-criticism in 1942, which makes it seem more like an act of survival than a genuine statement of her belief. However, she re-articulated and reaffirmed this view in the 1980s. See Yan (2006: 286).
} 
of gender-equal consciousness amongst some of her male counterparts as one of the obstacles that prevents women from participating further in the revolution, which, in her view, consequently hinders the progression of social and political change.

The most prominent example in In the Hospital can be found in her depiction of male leaders' indifference toward female cadres:

The director of the hospital is from Sichuan, originally a peasant who later joined the revolution. He has worked in the army for a long time, but is an amateur of medical studies. He greets Lu Ping with an attitude implying that greeting female comrades with respect and hospitality is unnecessary. He reads her recommendation letter as if he is reading a receipt of the purchase of animal feed. Then he casts a glance at her casually and said: "Well, very good! Stay here." He is very busy and cannot talk to her for longer (Hospital, 240).

Here, the depiction of the leader's apathetic attitude highlights Ding Ling's criticism of gender hierarchy in Yan'an, which is intertwined with an implicit critique of a romanticised view of peasants. It seems that the leader's peasant background accounts for his lack of any sense of gender equality and political consciousness, which also leads to his poor leadership and management, yet Ding Ling is not concerned with depicting male peasants as necessarily backward-thinking or revolutionary. Rather, she rejects a dichotomous depiction of characters in her literary writing, exploring instead the complexity and diversity of these figures. Furthermore, the negative view of the leader is depicted from Lu Ping's perspective, which complicates our understanding of Ding Ling's attitude towards peasants: this negative perception is at the same time a complaint about the peasants upholding such a negative view of women and a criticism of Lu Ping's bourgeois-mindedness.

However, towards the end of the novel, Ding Ling also articulates her respect for the peasants through the words of the patient, who is a student and, for Lu Ping, a like-minded person. It is also this patient who teaches Lu Ping the importance of "growing up in hardship" (Hospital, 253). While acknowledging 
Lu Ping's dismay regarding the leader's peasant background, the patient states that although Lu Ping has more knowledge than the peasants, they are better at doing actual deeds in everyday life (Hospital, 253). He goes on and criticises Lu Ping, stating that "in a relentless self-struggle, it would not be easy to pull oneself together" (Hospital, 253) -this criticism enables Lu Ping to relinquish her self-consciousness, which reinforces Ding Ling's call for collaborative efforts to build a space for women that is liveable. Ding Ling's ambivalent view of the peasants here complicates the depiction of the characters-they are not portrayed as completely likeable nor unpleasant. Instead, each prototypical character has his or her own failings, but at the same time, these characters also exhibit features with which readers may sympathise. In this sense, Ding Ling conceptualises literature as a space in which complex characters with all their positive and negative aspects can be created; only in this imaginative literary space can true equality in socialist society emerge.

Ding Ling's exploration of the complexity of characters is part of the debates that took place in the 1930s and 1940s on how best to represent "the people" in literature and the arts. Writers like Ding Ling and Hu Feng believed that complexity within characters, including their inner struggles, should be depicted in literature, whereas others, such as Zhou Yang, contended that only the positive aspects of "the people" - the workers, peasants and soldiers-should be depicted and negative aspects should not be exposed, a view which was reinforced by Mao in his "Talks on the Yan'an Forum of Art and Literature" (1942) (Denton, 1998). In this context, Ding Ling's ambivalent depiction of the male peasants and cadres was problematic for Mao, as he believed that "true revolutionary knowledge and creativity ultimately emanates from the people [peasants] themselves" (Meisner, 1999: 44).

Ding Ling's negative depiction of "the people" and her emphasis on women's self-improvement attracted considerable criticism, though primarily from male critics (Ding Ling, 1982b: 279). Ironically, the reactions and criticism from Ding Ling's male contemporaries exemplify exactly what Ding Ling was criticising through her writings. While Feuerwerker suggests that the reason for these critiques of Ding Ling by others lies in the fact that Ding Ling in Yan'an "no longer wrote to dramatise the struggles of the individual woman within herself but to attack hardships and discrimination particular to women in society" 
(Feuerwerker, 1977: 298), He Guimei, by contrast, interprets the criticism targeted at Ding Ling as a clash between Ding Ling's feminist perception of class and gender hierarchy in Yan'an and the CCP's male-oriented views on revolution (He, 2004). These scholars outline the incompatibility of Ding Ling's feminist outlook on the communist revolution with the CCP's gender policy that still discriminated against women, despite its egalitarian objectives. Nonetheless, Ding Ling's criticism of gender inequality should not only be examined through the lens of resistance to political pressure, but also through her own views on revolutionary transition and its relation to her self-scrutiny. In the early 1950s, Ding Ling recalled her Yan'an life retrospectively: "Some people are born revolutionaries, some people leap to become revolutionaries. [...] But I am always willing to walk step by step with my own legs, walk till there is genuine usefulness, till I am beyond myself, [...] till I have gained some knowledge and truth" (Ding Ling, 1950b: 50). This statement demonstrates Ding Ling's understanding of revolutionary transition as a difficult process that requires patience, perseverance and actual practice, which she, in turn, incorporated in the depiction and her own expectation of the female characters in herworks.

When Zhou Yang condemned Ding Ling as possessing a "decadent bourgeois mentality", he overlooked Ding Ling's "own lifelong struggle to shape her relationship to the spirit of the Chinese revolution that aimed to put an end to such a [class] hierarchy" (Yan, 2006: 205). Ding Ling's writings are concerned with the way in which revolution can bring about an overturn of social hierarchy and, on a personal level, an overcoming of one's weakness, which is articulated through her "critical mapping and ethical evaluation of the conditions uninhabitable for her female figures" (Yan, 2006: 200). For Ding Ling, building an equal socialist society requires a deep transformation of attitudes toward fellow humans at all levels; the complex depiction of the literary figures, encompassing their positive and negative aspects, can, at least, lead to a recognition and understanding of the difficulty of this transformation. In this regard, Ding Ling, through her literature, creates an imaginative space, in which she explores not only the relationship between individuals and the revolution, but also the extent to which individuals, especially women, as embodiments of the revolution, can improve their own capacity as revolutionaries and, above all, as human beings. And this is the space of solidarity that Ding Ling hopes to create for women. 


\section{Conclusion}

The terminologies and approaches that were used to represent Chinese women and women's liberation have shifted along with the changes in the political order since the early twentieth century. As Tani Barlow has illustrated, since the 1940s the Chinese Communist Party officially used the designation funü 妇女 to represent women as a socialist collectivity under the purview of the state (Barlow, 2004). Funü women were aligned with the priorities of the state's definition of women's liberation as resulting from women's productive social labour and participation in the building of the communist society. As Barlow notes, the use of funü was meant to contrast with ideas of women's liberation associated with other terms for the women's movement and women in general, such as nüxing and nüquan, circulating since the early twentieth century (Barlow, 2004). The term funü, while signifying an important aspect of the socialist view of women's oppression as being rooted in the unequal politicaleconomic structures of feudalism and capitalism, often precluded other aspects of gender inequality and sexism, including in the intimate and psychological realms. In the post-Mao era, however, with the accelerating economic development and the rise of consumerism, nüxing-a term that was denounced in the revolutionary period-seems to possess the potential of female resistance, as its emphasis on the sexist binary challenges the previous statist representation of women as largely rooted in political economy (Barlow, 2004: 63). Recently, however, in contemporary China as well as in Western countries, the political and economic crises have gradually pushed feminists to reconsider socialism as an alternative mode of female resistance against the recuperation of male dominance (Fraser, 2013).

It is in this context that Wang Zheng's book Finding Women in the State calls for a reconsideration of the socialist feminist legacy that has been long forgotten, hoping to search for new resolutions that provide women with different avenues to approach issues of solidarity and empowerment. She highlights that the state feminists working in the All-China Women's Federation operated in "a politics of concealment", incorporating feminist agendas into the Party's agenda "in order to gain legitimacy and resources for actions that had a clear gender dimension" (Wang, 2017: 17). While her analysis resurfaces the legacy of feminists who were tied to the state and the approach they adopted 
to resolve women's oppression within the Party's agenda, the feminist endeavour articulated by feminists that were not closely tied to state policy should also not be overlooked. The reading of Ding Ling and Christa Wolf thus provides an insight into the perspectives of feminists who upheld a socialist ideal of human relations while articulating their critical voices toward gender practices in socialism. They explore women's oppression in relation to its economic, political and cultural factors and strive to create a female solidarity that transcends all unequal social relationships.

Ding Ling's explicit criticism of gender inequality points towards a complex reality of gender issues in a socialist regime. By exposing the struggles women faced in the Communist base area in Yan'an in the 1940s, Ding Ling calls for collaborative work on gender equality not only through official policy-making, but also through the efforts of both men and women overcoming their own failings in affecting a transformation of gender and other social relationships in their daily lives. In doing so, Ding Ling's zawen-like novel functions as a "microscope", according to Lu Xun's term, that magnifies and scrutinises the messy parts of reality, rather than just focusing on unrealistic positive depictions, through which a more nuanced and realistic image of life can emerge in literature (Lu Xun, 1930). By contrast, Christa Wolf depicts a female protagonist who fails to conform to the expectations of the society around her, and, in turn, strives to counter masculine dogmatism in socialism with her own imagination and literary recreation. This literary imagination envisions a more diverse socialism, in which female bonding and solidarity seem to be an alternative form of human interrelationship in a socialist society that looks forward into the future.

Both authors expose the complex intertwining of social hierarchies in socialist states from women's perspectives, through which they demonstrate a futureoriented vision of socialism in their writings by incorporating their criticism of socialism with their engagement with the struggle of women to obtain their own rights. The protagonist Lu Ping in Ding Ling's Hospital appears to be what Barlow terms a good example of "Ding Ling's problem of futurity and normativity, or what women can expect to become if they commit themselves as a gender to the revolutionary future" (Barlow, 2004: 222). In this sense, the future-oriented focus of Ding Ling's novel is embedded in her criticism of the gap between the 
ideal and the reality of gender inequality, implying a more urgent question of "what can still be done"?

Writing from a similar perspective to Ding Ling, Wolf relies on imagination to bring about the future of socialism. As Kuhn suggests, "it is precisely the imagination, by stretching the parameters of human thought, possibility, and potentiality, that can perpetuate the socialist utopian vision" (Kuhn, 1988: 74). In other words, Wolf's outlook on the future seems to be a vision of a less restrictive socialist system, in which female solidarity can lead to an actual equality between men and women.

Both Ding Ling and Christa Wolf suggest the idea of female solidarity as a hope and a means of bringing forth social changes through a feminist approach that strives to transform hierarchical human relationships. The reading of the history of this female solidarity within a Chinese and a transnational socialist context does not reiterate an understanding of gender that overlooks differences. Rather, it envisages a socialist outlook that adopts, in Nancy Fraser's term, the politics of redistribution as well as those of recognition (Fraser \& Honneth, 2003). From a transnational socialist feminist perspective, this comparative analysis offers an insight into an understanding of the complexity and difficulty women face in their struggles to gain true equality. The reading of such endeavours, to make sense of the complex picture of the experience of women under socialist regimes, aspires to a possible future for feminism in China which in turn resonates with the female solidarity for which feminists in the past strove.

\section{References}

Apter, David E. and Tony Saich (1994), Revolutionary Discourse in Mao's Republic, Cambridge: Harvard University Press.

Barlow, Tani E. (2004), The Question of Women in Chinese Feminism, Durham and London: Duke University Press.

Boxer, Marilyn J. (2007), "Rethinking the Socialist Construction and International Career of the Concept 'Bourgeois Feminism'”, The American Historical Review 112(1): 131-158. 
Buchanan, Ian (2016), A Dictionary of Critical Theory, Oxford: Oxford University Press.

Dai, Jinhua (2004), "Class and Gender in Contemporary Chinese Women's Literature", 289-306, in Tao Jie, Zheng Bijun and Shirley L. Mow (eds.), Holding Up the Half Sky: Chinese Women Past, Present and Future, New York: The Feminist Press, City University of New York.

Denton, Kirk (1998), The Problematic of Self in Modern Chinese Literature, Stanford: Stanford University Press.

Dikötter, Frank (1995), Sex, Culture and Modernity in China: Medical Science and the Construction of Sexual Identities in the Early Republican Period, London: Hurst \& Company.

Ding, Ling (1941a), "Zai yiyuanzhong” (In the hospital), 234-253, Ding Ling quanji 4 (2001), Shijiazhuang: Hebei renmin chubanshe.

- - (1941b), "Women xuyao zawen (We need critical essays)", 58-59, Ding Ling quanji 7 (2001), Shijiazhuang: Hebei renmin chubanshe.

- - (1942a), "Thoughts on March 8", 316-321, in Tani E. Barlow and Gary J. Bjorge (eds.) (1989), I Myself Am a Woman: Selected Writings of Ding Ling, Boston: Beacon Press.

- - (1942b), "Guanyu zai yiyuanzhong" (About In the Hospital), Zhongguo xiandai wenxue yanjiu congkan, (2007), 6: 97-114.

- - (1950a), "Laodong yu wo (Labour and I)", in Li Xiangdong and Wang Zengru (2015), Ding Ling zhuan (Ding Ling's biography), Beijing: Zhongguo da baike quanshu chubanshe.

- - (1950b), "Shanbei fengguang jiaohou ji" (Afterword of Shanbeifengguang), 50-53, Ding Ling quanji 9 (2001), Shijiazhuang: Hebei renmin chubanshe.

- - (1982a), "Wo yu xiju" (I and drama), 156-163, Ding Ling quanji 9 (2001), Shijiazhuang: Hebei renmin chubanshe.

- - (1982b), "Yan'an wenyi zuotanhui de qianqianhouhou" (Before and after the Yan'an forum of literature and art), 263-283, Ding Ling quanji 10 (2001), Shijiazhuang: Hebei renmin chubanshe.

Dooling, Amy (2017), "Representing Dagongmei (Female Migrant Workers) in Contemporary China", Frontiers of Literary Studies in China, 11(1): 133156.

Ehrenreich, Barbara (1976), What is Socialist Feminism?, n.p.: Nationwide Women's Program.

Feuerwerker, Yi-tsi Mei (1977), “The Changing Relationship Between Literature 
and Life: Aspects of the Writer's Role in Ding Ling", 281-307, in Merle Goldman (ed.), Modern Chinese Literature in the May Fourth Era, Cambridge and London: Harvard University Press.

- - (1982), Ding Ling's Fiction: Ideology and Narrative in Modern Chinese Literature, Cambridge: Harvard University Press.

Fraser, Nancy (2013), Fortunes of Feminism: From State-managed Capitalism to Neoliberal Crisis, New York: Verso Books.

Fraser, Nancy and Axel Honneth (2003), Redistribution or Recognition?: A Political-philosophical Exchange, London: Verso.

Fulbrook, Mary (2004), A Concise History of Germany, Cambridge: Cambridge University Press.

Gao, Hua (2000), Hongtaiyang shi zenyang shengqi de: Yan'an zhengfeng yundong de lailongqumai (How did the sun rise over Yan'an? A history of the rectification movement), Hong Kong: Chinese University of Hong Kong.

Gilmartin, Christina (1995), Engendering the Chinese Revolution: Radical Women, Communist Politics, and Mass Movements in the 1920s, Berkeley: University of California Press.

Haase, Horst (1969), "Nachdenken über ein Buch. Christa Wolf: Nachdenken über Christa T.", Neue Deutsche Literatur, Heft 4: 174-185.

Haslanger, Sally, Nancy Tuana and Peg O'Connor (2017), "Topics in Feminism", in Edward N. Zalta (ed.), The Stanford Encyclopedia of Philosophy, available at: https://plato.stanford.edu/entries/feminist-philosophy/\#Top

iFemi (accessed 10.07.2018).

Hathaway, Michael J (2018), "China's Forgotten Role in Western Second-Wave Feminism", AsiaGlobal Online, January 4, available at: http://www.asiaglo balonline.hku.hk/making-the-global-chinas-forgotten-role-in-western-sec ond-wave-feminism/ (accessed 10.07. 2018).

He, Guimei (2004), "Zhishi fenzi, nüxng yu geming-cong Ding Ling ge'an zhong kan Yan'an linglei shijian zhong de shenfen zhengzhi (Intellectuals, women and revolution-Ding Ling as a case study of alternative practice of identity politics in Yan'an)", Dangdai zuojia pinglun (Contemporary writers review), vol. 3: 112-127.

Hell, Julia (1997), Post-Fascist Fantasies: Psychoanalysis, History, and the Literature of East Germany, Durham: Duke University Press.

Hong, Zicheng (2007), A History of Contemporary Chinese Literature, trans. by Michael M. Day, Boston: Brill. 
Hsiung, Ping-Chun and Yuk-Lin Renita Wong (1999), "Jie Gui-Connecting the Tracks: Chinese Women's Activism Surrounding the 1995 World Conference on Women in Beijing", 126-153, in Mrinalini Sinha, Donna Guy and Angela Woollacott (eds.), Feminism and Internationalism, Oxford: Blackwell Publishers.

Huyssen, Andreas (1975), "Auf den Spuren Ernst Blochs. Nachdenken über Christa Wolf", Basis 5: 100-116.

James, Susan (1998), “Feminism", 576, in Edward Craig (ed.), Routledge Encyclopedia of Philosophy (vol. 10), London: Routledge.

Kähler, Hermann (1969), "Christa Wolfs Elegie”, Sinn und Form, 1: 251-261.

Kollontai, Alexandra (1909), "Introduction to the Book The Social Basis of the Women's Question", in Alexandra Kollontai: Selected Articles and Speeches (1984), Moscow: Progress Publishers.

Kuhn, Anna (1988), Christa Wolf's Utopian Vision: From Marxism to Feminism, Cambridge: Cambridge University Press.

Li, Xiangdong and Wang Zengru (2015), Ding Ling zhuan (Ding Ling's biography), Beijing: Zhongguo da baike quanshu chubanshe.

Liu, Lydia H., Rebecca E. Karl and Dorothy Ko (2013), The Birth of Chinese Feminism: Essential Texts in Transnational Theory, New York: Columbia University Press.

Liu, Wen, Ana Huang and Jingchao Ma (2015), "Young Activists, New Movements: Contemporary Chinese Queer Feminism and Transnational Genealogies", Feminism \& Psychology 25(1): 11-17.

Love, Myra (1979), "Christa Wolf and Feminism: Breaking the Patriarchal Connection", New German Critique 16: 31-53.

Lu, Xun (1930), "Zuo 'zawen' ye buyi" (Writing "zawen" is not easy either), Jiwaiji shiyi bubian (1993), Beijing: renmin wenxue chubanshe.

MacFarquhar, Roderick (1966), The Hundred Flowers Campaign and the Chinese Intellectuals, New York: Praeger.

Mayer, Hans (1970), "Christa Wolf, Nachdenken über Christa T.", Neue Rundschau, 1: 180-186.

McDougall, Bonnie S. and Kam Louie (1999). The Literature of China in the Twentieth Century, New York: Columbia University Press.

Meisner, Maurice (1999), Mao's China and After: A History of the People's Republic (3rd ed.). New York: The Free Press.

Mikus, Birgit and Emily Spiers (eds.) (2016), "Fractured Legacies: Historical, 
Cultural and Political Perspectives on German Feminism", special issue, Oxford German Studies 45(1).

Mohr, Heinrich (1971), "Produktive Sehnsucht. Struktur, Thematik und politische Relevanz von Christa Wolfs Nachdenken über Christa T.", Basis 2: 191-233.

Münkler, Herfried (1996), "Politische Mythen der DDR", BerlinBrandenburgischen Akademie der Wissenschaften, Jahrbuch: 123-156.

Paul, Georgina (2009), Perspectives on Gender in Post-1945 German Literature, Rochester: Camden House.

Reich-Ranicki, Marcel (1969), "Christa Wolfs unruhige Elegie”, Die Zeit, May 23, available at: https://www.zeit.de/1969/21/christa-wolfs-unruhige-elegie (accessed 10.07.2018).

Riddell, John (2011), "The Communist Women's Movement, 1921-26", International Socialist Review 87, available at: https://isreview.org/issue/8 7/communist-womens-movement (accessed 10.07.2018).

Rubin, Kyna (1981), "An Interview with Mr Wang Ruowang", The China Quarterly 87: 501-517.

Sachs, Heinz (1969), "Verleger sein heißt ideologisch kämpfen", Neues Deutschland, May 14.

Song, Shaopeng (2012), "Zibenzhuyi, shehuizhuyi he funü-weishenme Zhongguo xuyao chongjian Makesi zhuyi nüquan zhuyi pipan (Capitalism, Socialism and Women-why China needs to reconstruct Marxist feminist critique)", Wenhua zongheng 6: 98-112.

Stranahan, Patricia (1983), Yan'an Women and the Communist Party, Berkeley: Institute of East Asian Studies and Centre for Chinese Studies, University of California.

Subiotto, Arrigo (1994), "The Figure of the Worker in GDR Literature: Christa Wolf and the Socialist Realist Tradition", 127-140, in Ian Wallance (ed.), Christa Wolf in Perspective, Amsterdam: Rodopi.

Tate, Dennis (1988), "'Breadth and Diversity': Socialist Realism in the GDR", 6078, in Michael Scriven and Dennis Tate (eds.), European Socialist Realism, Oxford, New York and Hamburg: Berg.

- - (2007), Shifting Perspectives: East German Autobiographical Narratives Before and After the End of the GDR, New York: Camden House.

Von Ankum, Katharina (1992), Die Rezeption von Christa Wolf in Ost und West: Von Moskauer Novelle bis "Selbstversuch", Amsterdam: Rodopi. 
Wang, Zheng (2000), "Feminism: China", 736-739, in Cheris Kramarae and Dale Spender (eds.), Routledge International Encyclopedia of Women: Global Women's Issues and Knowledge, New York and Oxford: Routledge.

-- (2017), Finding Women in The State: A Socialist Feminist Revolution in the People's Republic of China, 1949-1964, California: University of California Press.

Wiegenstein, Rolf (1969), "Verweigerung oder Zustimmung", Merkur, 8: 779782.

Wolf, Christa (1968a), The Quest for Christa T. (1982), tran. by Christopher Middleton, London: Virago Press.

-- (1968b), "The Reader and The Writer", 177-212, in The Reader and The Writer: Essays Sketches Memories (1977), trans. by Joan Becker, Berlin: Seven Seas.

Yan, Haiping (2006), Chinese Women Writers and the Feminist Imagination, 1905-1948, London and New York: Rutledge.

Yin, Qi (2004), "Zhengfeng yundong hou de Ding Ling he Wang Shiwei, xiangtong guandian butong mingyun (Ding Ling and Wang Shiwei after the Rectification Movement, same opinion different ending)", Yanhuang chunqiu, 12.

Zetkin, Clara (1896), "Only in Conjunction with the Proletarian Women Will Socialism Be Victorious", in Philip Foner (ed.) (1984), Clara Zetkin:Selected Writings, New York: International Publishers.

Zhang, Guangnian (1958), "Shafei nüshi zai Yan’an-ping Ding Ling de zai yiyuan zhong (Miss Sophia in Yan'an-on Ding Ling's In the Hospital)", Wenyi bao 2: 9-11.

Yejun Zou is a PhD student in the Department of German at King's College London, and at the Humboldt University of Berlin. 